\title{
OPTIMALISASI PENGEMBANGAN DESAIN DESTINASI WISATA MENGGUNAKAN BAHAN MATERIAL KONSTRUKSI EKONOMIS SERTA RAMAH LINGKUNGAN DI DESA TRI RAHAYU
}

\author{
Fery Hendi Jaya ${ }^{1}$, Farida Juwita ${ }^{2}$ Gustaf Gautama $^{3}$ \\ Universitas Sang Bumi Ruwa Jurai
Prodi Teknik Sipil, Fakultas Teknikferyhjaya@gmail.com ${ }_{3}$, ida.juwitaft@gmail.com ${ }^{2}$
gustafgautama70@gmail.com ${ }^{2}$ \\ gustafgautama70@gmail.com
}

\begin{abstract}
Abstrak
Pariwisata merupakan industri yang kelangsungan hidupnya sangat peka terhadap kerusakan lingkungan oleh baik-buruknya lingkungan. Industri ini sangat peka terhadap kerusakan lingkungan, misalnya pencemaran oleh limbah domestik dan kerusakan pemandangan alam, serta sikap penduduk yang tidak ramah. Suatu daerah wisata mempunyai kemampuan tertentu untuk menerima wisatawan, yaitu disebut daya dukung lingkungan. Tatakelola tempat wisata tidak dapat memberikan kontribusi terhadap perkembangan ekonomi masyarakat jika tidak dikelola secara maksimal. Objek- objek wisata di Provinsi Lampung, terutama di Kabupaten Pesawaran khususnya, belum secara maksimal dikembangkan dengan berbagai atraksi dan inovasi objek pariwisata. Salah satu objek wisata yang dapat dikembangkan di desa Tri Rahayu yakni kolam renang alami dan akses keindahan alam desa pertanian jagung yang terkoneksi dengan pasar tradisional (yang saat ini telah dikembangkan walau tanpa konsep akademik), dibutuhkan inovasi, kreativitas, bentuk seni konstruksi yang diperlukan juga promosi yang dilakukan secara kontinyu. Untuk melakukan semua pengelolaan lingkungan fisik dan sosial diperlukan ketrampilan dan keahlian di bidang pariwisata,maka dari itu sumber daya manusia dari masyarakat setempat sangat perlu ditingkatakan. Berbagai usaha sangat penting dilakukan dan ditingkatkan oleh pemerintah maupun swasta untuk terus memajukan dan mengembangkan obyek wisata kolam renang yang dapat dikemas secara ekonomis dan dikembangkan secara ilmu teknik sipil dalam dunia pariwisata dengan tetap mempertahankan keasrian dari alamnya serta ramah lingkungan yang dapat menarik wisatawan.
\end{abstract}

Kata Kunci: pariwisata ,tatakelola,ekonomis ,ramah lingkungan.

\begin{abstract}
Tourism is an industry whose survival is very sensitive to environmental damage caused by the environment. This industry is very sensitive to environmental damage, for example pollution by domestic waste and damage to natural landscapes, as well as the unfriendly attitude of the population. A tourist area has a certain ability to receive tourists, which is called the carrying capacity of the environment. The management of tourist attractions cannot contribute to the economic development of the community if it is not managed optimally. Tourist objects in Lampung Province, especially in Pesawaran District in particular, have not been maximally developed with various attractions and tourism object innovations. One of the tourist objects that can be developed in Tri Rahayu village, namely a natural swimming pool and access to the natural beauty of the corn farming village which is connected to a traditional market (which has been developed even without an academic concept), it requires innovation, creativity, the art form of construction that is needed as well. promotions are carried out continuously. To carry out all management of the physical and social environment requires skills and expertise in the field of tourism, therefore human resources from the local community need to be improved. Various efforts are very important to be made and increased by the government and the private sector to continue to promote and develop swimming pool tourism objects that can be packaged economically and developed in civil engineering in the world of tourism while maintaining the beauty of nature and being environmentally friendly that can attract tourists.
\end{abstract}

Keywords: tourism, governance, economical, environmentally friendly. 


\section{PENDAHULUAN}

Saat ini, perkembangan pariwisata makin kian berkembang pesat, dunia pariwisata telah mengalami berbagai perubahan baik perubahan pola, bentuk dan sifat kegiatan, dorongan orang untuk melakukan perjalanan, cara berpikir, maupun sifat perkembangan itu sendiri.

Pariwisata merupakan industri yang kelangsungan hidupnya sangat peka terhadap kerusakan lingkungan oleh baik-buruknya lingkungan. Industri ini sangat peka terhadap kerusakan lingkungan, misalnya pencemaran oleh limbah domestik dan kerusakan pemandangan alam, serta sikap penduduk yang tidak ramah. kekurangan sarana prasaran dalam menciptakan pariwisata yang kondusif. Wisatawan hanya dapat menikmati keindahan alam, tanpa ada layanan pariwisata alam lainnya. Hal ini menyebabkan ketidak merataan penyebaran kunjungan para wisatawan. Salah satu objek wisata yang dapat dikembangkan di desa Tri Rahayu yakni kolam renang alami dan akses keindahan alam desa pertanian jagung yang terkoneksi dengan pasar tradisional (yang saat ini telah dikembangkan walau tanpa konsep akademik. Desa Wisata Tri Rahayu merupakan sebutan bagi Desa Tri Rahayu, Kecamatan Negeri Katon Kabupaten Pesawaran. Desa Tri Rahayu memiliki keunikan dan keindahan alamnya yang benar-benar masih alami dan asri. Desa tersebut merupakan salah satu Desa yang berada di tengah-tengah akses transportasi bandara, akses universitas, pemda, dan penghubung antar kabupaten maupun kota di provinsi Lampung.

\section{Permasalahan Destinasi Wisata Desa Tri Rahyu}

Dari hasil identifikasi, observasi dan analisis terhadap permasalahan yang dihadapi dan harus dipecahkan solusi yang terbaik oleh "Team Pendamping", sebagai berikut:

1. Minimnya tenaga/sumber daya manusia (SDM) sesuai kebutuhan tata kelola desa wisata dan UMKM yang saat ini telah dilaksanakan.

2. Belum adanya Grand Design dan data up to date pengembangan desa wisata di desa Tri Rahayu.

3. Kurangnya pengetahuan, kemampuan dan etika dalam pengelolaan organisasi desa (BumDes) sesuai standarisasi legalitas yang telah ditetapkan oleh Pemerintah Daerah Provinsi Lampung.

4. Lemahnya daya tarik dan keinginan dalam memajukan potensi desa yang saat ini masih terkesan lokal dan konvensional.

5. Kurangnya pembinaan dan pendampingan secara kontinyu baik berupa pelatihan-pelatihan, sosialisasi dan workshop untuk menunjang kegiatan eksploitasi desa wisata.

\section{METODE PENELITIAN}

Metode pelaksanaan pendampingan pengabdian pengembangan potensi desa wisata yakni dengan menerapkan konsep penerapan ilmu sesuai kompetensi yakni design gambar (program AutoCad dan lummion) dan praktik pelaksanaan konstruksi kerja konstruksi.

\section{Prosedur Pengukuran Dan Inventarisir Data Existing}

Didapatkanya data awal (existing) sebelum pengembangan rancangan potensi desa wisata sebagai berikut :

1. Observasi dan survey lahan dan lokasi potensi desa wisata (kolam renang)

2. Tahap pengukuran dan inventarisir kondisi fisik konstruksi yang ada.

3. Tahap draft rancangan potensi wisata secara menyeluruh.

\section{Prosedur Pengolahan/Rancangan Pengembangan}


Selanjutnya tahapan pengolahan dan desain data sebagai berikut :

1. Desain dan pembuatan RAB serta spesifikasi teknis pengembangan potensi wisata kolam renang.

2. Pelatihan pengetahuan tentang pelaksanaan teknis konstruksi (Tata cara kerja, material/bahan ramah lingkungan dan peralatan)

3. Pelatihan manajemen konstruksi potensi desa wisata kolam renang.

4. Pendampingan dan konsultasi

\section{Spesifikasi Rancangan Kegiatan.}

Daya dukung pelaksanaan spesifikasi rancangan ini sangatlah mutlak dan dapat terealisasi sesuai dengan harapan bersama jika dibuatkannya network planning atau rancangan jadwal tahapan kegiatan, yang berisikan administrasi; durasi waktu, biaya, dan mutu capaian, baik dalam segi perencanaan, pengawasan, pelaksanaan dan evaluasi personal SDM yang terlibat baik langsung maupun tidak langsung dalam pengembangan potensi wisata.

Partisipasi Mitra Dalam Pelaksanaan Pengembangan Potensi Desa Wisata. Partisipasi kemitraan dalam pelaksanaan pendampingan pengembangan potensi desa wisata ini tidaklah dapat tercapai dengan baik dan sempurna jika pihak-pihak stakeholder, pemerintah (Pemda Kabupaten Pesawaran), Dinas PU Pesawaran, perguruan tinggi, pelaku pengelola wisata daerah dan masyarakat harus terlibat secara kontinyu. Dengan demikian langkah konkrit yang dilaksanakan berupa Memorandum of Understanding (MOU) kepada pihak-pihak yang terkait dan terlibat dalam pelaksanaan diatas guna tercapainya pengembangan wisata desa dan akuntabilitas program yang baik ini.

\section{HASIL DAN PEMBAHASAN}

\section{Hasil yang Dilaksanakan}

Hasil dalam pelaksanaan kegiatan pengabdian kepada masyarakat ini dapat dirangkum sebagai berikut:

a. Terjalinnya kerjasama antara masyarakat, pengelola BumDes dan aparat kelurahan/desa terutama pada peningkatan sumber daya manusia secara manajerial dan tata Kelola teknis pengembangan wisata kolam di desa Tri Rahayu, Kecamatan Negeri Katon Kabupaten Pesawaran.

b. Terbentuknya wadah dan organisasi pengelolaan pengembangan wisata kolam dari beberapa unsur masyarakat, dalam menghadapi pengembangan wisata berupa penggunaan teknologi informasi \& komunikasi (internet), promosi, administrasi dan pengembangan pisik wisata kolam.

c. Menghasilkan Grand Design Pengembangan wisata dengan menggunakan bahan material konstruksi (local) yang ekonomis serta ramah lingkungan di Desa Tri Rahayu, Kabupaten Pesawaran.

(Bentuk hasil pengabdian, Vidio dapat dilihat pada lampiran pengabdian ini.)

\section{Kendala Pelaksanaan}

Dalam Pelaksanaan ini memang banyak kendala yang dirasakan namun ada beberapa yang menjadi perhatian untuk disikapi, sebagai berikut: 
a. Adanya perbedaan pendapat dan keinginan yang berbeda (singkronisasi) dari para pengelola destinasi wisata kolam, maupun Kepala Desa

b. Minimnya pengetahuan dan informasi secara legal (aturan hukum) dan pemahaman tentang teknis serta anggaran biaya dalam mewujudkan pelaksanaan pengabdian ini.

c. Kurangnya keterbukaan, baik aparat kelurahan, pengelola terhadap masyarakat terlebih tim pengabdian dalam pelaksanaan optimalisasi pengembangan wisata di Desa Tri Rahayu, Kecamatan Negeri Katon Kabupaten Pesawaran.
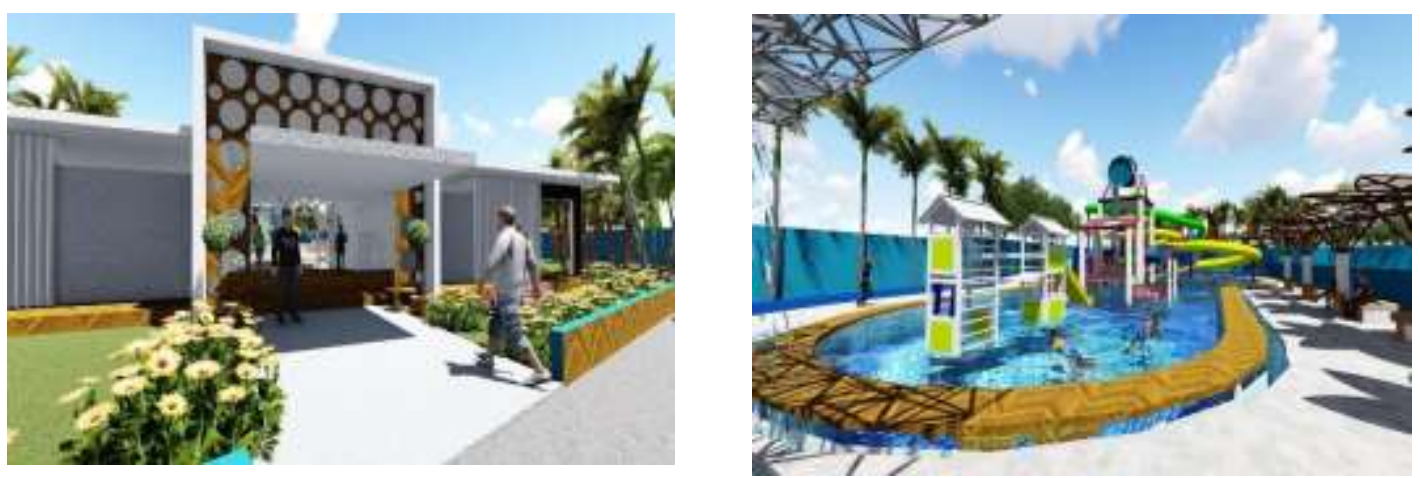

\section{Gambar Desain Kolam Wisata 1 -4}
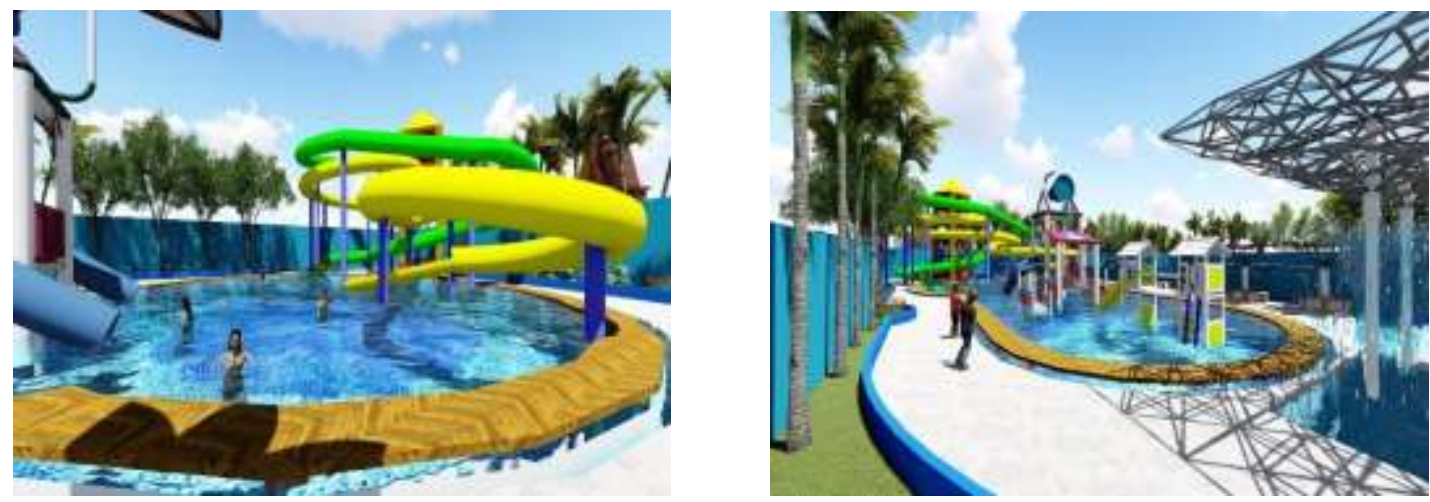

GAMBAR DESAIN KOLAM WISATA 5 \& 6
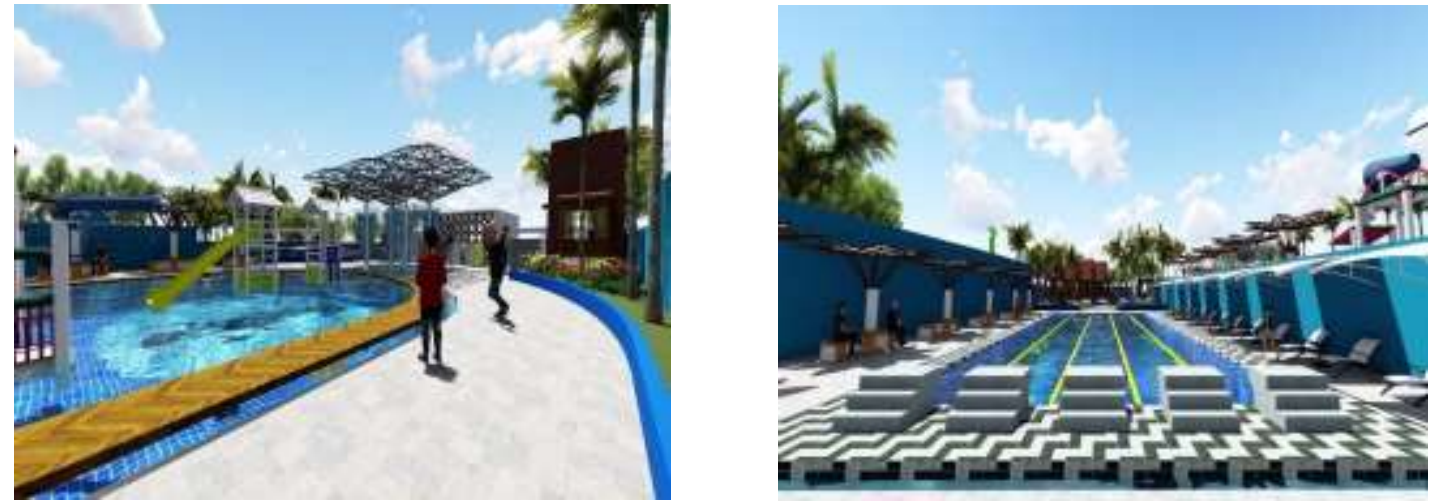
Seminar Nasional Penelitian dan Pengabdian kepada Masyarakat Universitas Sang Bumi Ruwa Jurai Tahun 2020

\section{GAMBAR DESAIN KOLAM WISATA 7 - 14}
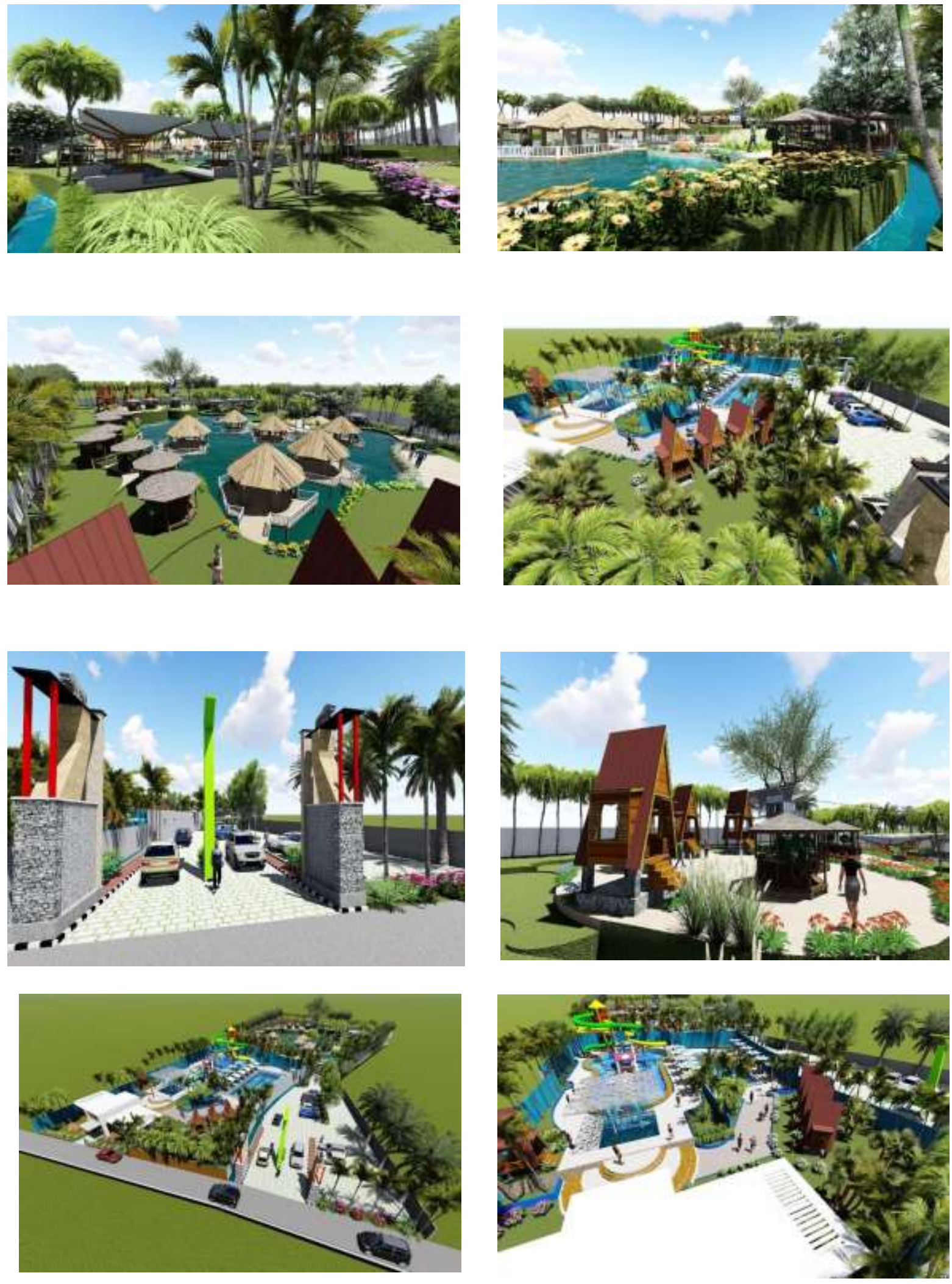


\section{KESIMPULAN}

Pelaksanaan kegiatan pengabdian kepada masyarakat ini dapat ditarik beberapa kesimpulan sebagai berikut:

1. Adanya peningkatan sumber daya manusia (SDM) di bidang administrasi dan pengorganisasian tentang pengembangan wisata daerah yakni kolom renang wisata.

2. Terbentuknya karakter dan etos kerja dalam penanganan pengembangan objek wisata desa baik dalam penggunaan Informasi Teknologi (IT) maupun teknis pengembangan secara visual.

3. Membantu kinerja pemerintah daerah dalam hal ini Dinas Pariwisata dalam mewujudkan pengembangan destinasi dalam bentuk optimalisasi Desain pengembangan teknis, terhadap penggunaan material lokal secara ekonomis dan ramah terhadap lingkungan.

\section{UCAPAN TERIMAKASIH}

Kami selaku Tim Pengabdian yang beranggotakan Dosen dan Mahasiswa , mengucapkan terimakasih kepada Lembaga Penelitian Dan Pengabdian Masyarakat (LPPM) Universitas Sang Bumi Ruwa Jurai yang telah memberikan kepercayaan dan mendanai kegiatan ini tak terkecuali kepada Ibu Rektor yang selalu memberikan bantuan, support dan inovasi agar kegiatan ini bisa dilaksanakan dengan lancar dan baik, Dan kepada Dekan Fakultas Teknik serta rekan-rekan dosen,karyawan/staf yang selalu menunggu keberhasilan Tim dalam menjalankan pengabdian sebagai bentuk Tri Dharma Perguruan Tinggi.

\section{DAFTAR PUSTAKA}

Fery HJ, 2019. Rangkuman Diktat Ajar FT. Auto Cad 2D \& 3D dan Penggunaan Program Lumion Bagi Perancang Dan Arsitek. Univ.Saburai Lampung.

Otobiografi Desa Tri Rahayu 2019, Data desa dan potensi wisata. Pesawaran Lampung.

Rio Manullang 2015, Menghitung Biaya Bangunan Serta Karakteristik Material,etc . Penerbit Andi Yogyakarta.

Robert J.K \& Roestam Sjarif. 2010, Tata Ruang Air ,Bencana, Pengelolaan Infrastruktur, Penataan Ruang Wilayah \& Pengelolaan Lingkungan Hidup. Penerbit Andi Yogyakarta

Salmani. 2014, Rekayasa Dan Penyediaan Air Bersih. Penrbit Deepublish

Yogyakarta. 